\title{
Globalization: Will China Change the World?
}

Hiroyuki KATO

\begin{abstract}
This article illustrates the current status of a globalizing China and discusses the effect of the rise of China on the global economy as well as its consequent changes. Globalization in China should be put in perspective from a historical point of view in order to gain a correct understanding of the changes taking place in China now. In the past, China was one of several core regions in the world, and there seems little doubt that it will reclaim this status in the near future. However, in order for China to regain and maintain its core-region status, China needs to shift from a resource-/energyintensive, foreign demand-dependent development model to a resource-/energyconserving, domestic demand-led development model.
\end{abstract}

\section{Keywords}

globalization, China's "resurgence", reform and opening-up policy, market transition, uncertainty in the global economy, development model, paradigm shift

\section{Introduction}

China has been steadily globalizing since the reform and opening-up policy was implemented in 1978. In the 30 years since the reform and opening-up policy was implemented, foreign companies have flocked to China, which prompted the country to catch up with global standards in various areas such as corporate governance, the legal system and business practices. In other words, the world has changed China in the past 30 years. However, it might be China's turn to change the world in the next 30 years. While the rise of China and other emerging economies has the potential to bring about unprecedented prosperity to the global economy, this is increasing uncertainties on many levels by posing a heavier burden on the environment, causing conflicts over resources, clashes between developed countries and developing countries in the developing markets, and instability in the global financial system. This series 
of changes suggests a possible paradigm shift in which the global economic order and market economy rules created by developed countries are completely overturned and a drastic change in the global economy takes place.

This article illustrates the current status of a globalizing China and discusses the effect of the rise of China on the global economy as well as its consequent changes. Globalization in China should be put in perspective from a historical point of view in order to gain a correct understanding of the changes taking place in China now. In the past, China was one of several core regions in the world, and there seems little doubt that it will reclaim this status in the near future. However, in order for China to regain and maintain its core-region status, China needs to shift from a resource-/ energy-intensive, foreign demand-dependent development model to a resource-/energyconserving, domestic demand-led development model.

Section 1 reviews the process of China's globalization in the 30 years of the reform and opening-up policy. Section 2 highlights the uncertainties that China has created for the global economy. Section 3 discusses the significance of China's "resurgence" from a historical point of view.

\section{Globalization and 30 Years Since the Imple- mentation of the Reform and Opening-Up Policy}

\section{Policy of Opening-Up to the Foreign Investment}

The bold policy of opening-up to foreign businesses is one of the pillars of the reform and opening-up policy. While the Chinese government requested loans from foreign governments and international institutes, it put forward a policy to actively attract direct foreign investment by establishing four "Special Economic Zones" in Shenzhen, Zhuhai, Shantou (all three in Guangzhou Province) and Xiamen (in Fujian Province) in 1980 to serve as bases for the policy of opening-up to the foreign businesses (Hainan Province was also designated as a Special Economic Zone later). Special Economic Zones served not only as an export processing base, but also as an entrance to accept foreign capital and technology. Foreign business could enjoy preferential tax treatment and the government heavily invested in social infrastructure projects in the Special Economic Zones. Fourteen coastal cities were opened to foreign investment in 1984, followed by the opening of Yangtze, Zhujiang and Minnan deltas as well as Liaodong Peninsula and Shandong Peninsula. Regions subject to the policy of opening up to foreign investment expanded from localized points to wide-ranging areas. In 1992, the middle and upper reaches of the Yangtze river and remote inland areas followed suit, and China entered a phase of "all-round opening up" in which the entire nation opened up to foreign investment.

The reform and opening-up policy was highly successful. The accumulated direct 
foreign investment amount reached 942.6 billion dollars by the end of 2009 on a settlement basis (but more than $90 \%$ of this was investments made no earlier than 1991). In addition to aggressive preferential tax treatment for foreign companies by the government, the ability to offer a low-cost processing base for companies from Newly Industrized Economies (NIEs) and Japan's struggle with the rapid appreciation of the yen since the Plaza Accord in 1985 contributed to this success. In particular, South China, where Fujian Province and Guangdong Province, which are close to Hong Kong and Taiwan, are located, attracted a large number of foreign companies mostly engaged in "contract proces-sing"1 Other export promotion policies were implemented along with a wider acceptance of foreign investments, including the devaluation of the yuan and the introduction of a system that allows companies and local governments to reserve foreign currencies. China's accession to the WTO in 2001 symbolized the integration of China into the global economy.

Furthermore, the government made a transition from the fixed exchange rate system to the managed floating system in 2005 as exports steadily increased. China had employed a system in which the Yuan was pegged to the Dollar for many years, but managed a transition to gradually appreciate the Yuan. As a result, the Yuan appreciated by approximately 25\% against the Dollar by 2010 .

\section{Increasing Connection with International Market}

In 2010, China surpassed Japan in GDP to become the second largest economy in the world after the United States. Advances in the areas of trade and direct investment are especially remarkable. Based on the statistics of the International Monetary Fund (IMF), China's share in the global trade increased dramatically from 1\% in 1980 to $10.5 \%$ in 2010 on an export basis.

One of the indexes to measure the progress of globalization is a shift in trade dependency (the ratio of exports and imports to GDP). Countries with large GDP usually have low trade dependency, but China is an exception. The trade dependency of China grew steadily from $9.8 \%$ in 1978 to a record high of 66.5\% in 2006 (Japan's trade dependency was $31.7 \%$ as of 2008), although it started to fall after that partly due to the government's intention to expand domestic demand.

China's advance is particularly of note in its relations with Asian and African countries. Table 1 shows the top 20 countries in terms of dependency on China for trade (the ratio of trade with China to total amount of trade). It is understandable that neighboring countries such as Mongolia (52.3\%), Kyrgyzstan and North Korea are at the top of the list, but it deserves particular mention that African countries such as Sudan, Benin, Angola and Togo also rank high. The number of the countries and

\footnotetext{
${ }_{1}^{1}$ The process in which all raw materials and equipment are provided by foreign investors and all of the processed products are exported while local manufacturers only earn processing fees. This was prevalent in Guangdong Province.
} 
region whose trade with China accounted for more than $20 \%$ of their total trade was three in Asia and one in Africa in 2001, but this number increased to ten in Asia and eight in Africa by 2009.

\begin{tabular}{r|c|l|l}
\hline \multicolumn{2}{c|}{ ranking } & country/region & ratio \\
\hline 1 & $(3)$ & Mongolia & 52.3 \\
\hline 2 & $(1)$ & Hong Kong & 48.7 \\
\hline 3 & $(20)$ & Kyrgyzstan & 46.8 \\
\hline 4 & $(6)$ & North Korea & 39.2 \\
\hline 5 & $(2)$ & Sudan & 38.4 \\
\hline 6 & $(48)$ & Benin & 35.3 \\
\hline 7 & $(17)$ & Angola & 30.1 \\
\hline 8 & $(102)$ & Togo & 28.7 \\
\hline 9 & $(4)$ & Macau & 28.5 \\
\hline 10 & $(59)$ & Solomon Islands & 27.7 \\
\hline 11 & $(9)$ & Myanmar & 25.0 \\
\hline 12 & $(64)$ & Mauritania & 24.7 \\
\hline 13 & $(129)$ & DR Congo & 24.4 \\
\hline 14 & $(163)$ & Tajikistan & 22.5 \\
\hline 15 & $(5)$ & Gambia & 21.9 \\
\hline 16 & $(11)$ & South Korea & 21.6 \\
\hline 17 & $(28)$ & Kazakhstan & 21.4 \\
\hline 18 & $(10)$ & Japan & 20.5 \\
\hline 19 & $(39)$ & Congo & 20.0 \\
\hline 20 & $(16)$ & Australia & 19.6 \\
\hline
\end{tabular}

Table 1: Trade Dependency Ratio to China

Note: Ranking in parenthesis is that of 2001 excluding Taiwan. Source: Nikkei Shimbun, July 18th, 2010.

China's foreign investment rapidly grew since the government had adopted a policy to promote China's foreign investment (the so-called "going-out" policy) in 1999. In 2008 , China was ranked $24^{\text {th }}$ in the world in terms of direct foreign investment balance (excluding the financial sector) at 183.97 billion dollars, and was ranked $11^{\text {th }}$ in the world and second in Asia behind Japan (ranked $6^{\text {th }}$ ) on an international balance of payments basis at 53.47 billion dollars.

China embarked on a mission to grow global companies that can be successful in the international market, and has attained some progress. According to a breakdown by country of the 500 largest companies in revenue compiled by Fortune in 2009, China was ranked $5^{\text {th }}$ at 37 companies (including 3 companies from Hong Kong) following the United States (140 companies), Japan (68 companies), France and Germany. Also, the list of top 10 companies in total market value as of June 2010 includes four Chinese companies: Petro China, Industrial and Commercial Bank of China, Mobile and China Construction Bank. 
Not only big firms, but an increasing number of IT and green business entrepreneurs are listed on the US stock market. In 2010, 41 Chinese companies went public in the New York Stock Exchange and NASDAQ, and the amount of raised capital reached 3.9 billion dollars, up $80 \%$ from the previous year. Chinese firms accounted for $27 \%$ of all the companies listed in the US stock market in the same year. ${ }^{2}$

\section{Market Transition Promoted by Opening-up Policy}

The development of the opening-up policy inevitably has a direct and indirect impact on the reform of the economic system. China set the "socialist market economy system" as a model to be aimed at, but this is not fundamentally different from economic systems adopted by developed capitalist countries. China is considered to have completed its market transition in a narrow definition ${ }^{3}$ around the year $2000 .{ }^{4}$ China's system gives the government more room to directly or indirectly intervene in the market compared to developed capitalist nations, but private firms, foreign based companies and state enterprises are fiercely competing against one another in both domestic and international markets.

Figure 1 shows the presence of foreign firms in the manufacturing sector. Foreign capital based companies, which did not exist in China before the introduction of the reform and opening-up in 1978, accounted for $18 \%$ of all companies, $30 \%$ of industrial output, $26 \%$ of total assets and $29 \%$ of the number of employees in 2008 . These figures show that foreign firms play a significant role in the manufacturing sector in China. Also, they account for $56 \%$ of Chinese exports in amount.

The significance of the rapid growth of foreign companies outweighs these figures. They brought global standards into China in various areas including corporate governance, the accounting system and business customs. Chinese domestic companies complied more closely with the global standards as they faced fierce competition from foreign companies. The opening-up policy propelled globalization at the corporate level and served as a driving force to accelerate market transition.

\footnotetext{
${ }^{2}$ The Nihon Keizai Shimbun (5 January 2011).

${ }^{3}$ The market transition in a narrow definition here means one satisfying two following conditions: 1) most of means of production are owned by privately and the private sector accounts for a large portion of GDP, and 2) the market is a dominating adjustment system of economic activities. However, China does not completely meet the condition of 1) as state-owned firms still occupy an important position in the country.

${ }^{4}$ Hiroyuki Kato, Toru Kubo, Shinka Suru Chugoku No Shihonshugi [China's Evolving Capitalism] (Tokyo: Iwanami Shoten, 2009).
} 


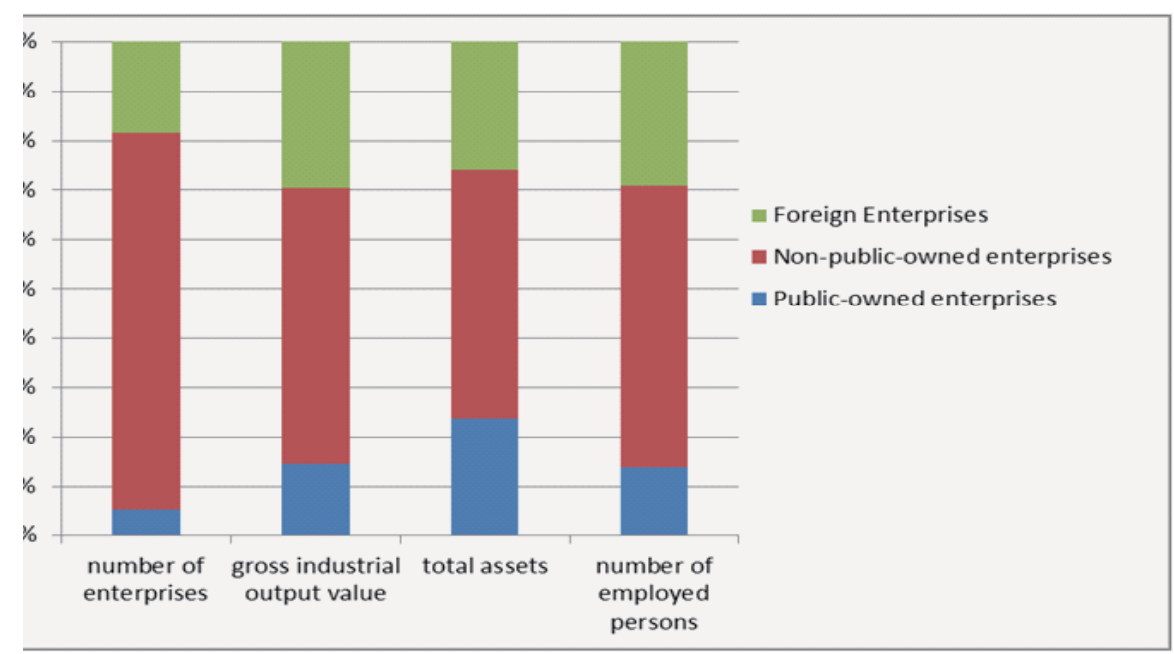

Figure 1: Share of Foreign Enterprises in Industrial Sector (2008)

Note: Public-owned enterprises include state-owned enterprises, state sole funded enterprises and collective-owned enterprises. Foreign enterprises include Taiwan, Hong Kong and Macau enterprises. Enterprises are those with annual revenue from principal business over 5 million Yuan.

Source: The author calculates figures from China Statistical Yearbook 2009.

\section{Uncertainty Created by a Rising China}

China has already begun to exercise influence in various fields of the global economy, but it is not clear yet whether this will reinforce the existing order of the global economy or will cause a realignment of the global economic order. The only thing certain at this point is that the rise of China has increased the amount of uncertainty in the global economy.

\section{Conflicts Over Resources}

China, having achieved rapid growth, emerged as a consumer of resources in the global market. Consequently, it sometimes fought with developed countries over resources and caused the rise and volatility of resource prices. Also, a long-practiced convention in resource price determination was broken by China. Furthermore, China's rather high-handed approach in securing resources is causing a political backlash from developed countries. Oil and iron ore are representative examples of this.

Figure 2 shows the trend of production and imports of crude oil in China. China is an oil-producing country and its oil output was 190 million metric tons in 2009. As of 1990, China was 100\% self-sufficient in crude oil, and its domestic output was enough to satisfy domestic demand. However, it started to import crude oil in the mid 90s as 
domestic demand grew. Imports steadily increased to a level that exceeded domestic production. According to future forecasts, China's foreign dependence on oil will rise to $64 \%$ by 2020 , as its crude oil production is expected to peak at around 200 million metric tons whereas import will continue to grow. ${ }^{5}$ A stable supply of oil is a crucial element for the sustainable development of the global economy, but the rise of China is complicating this.

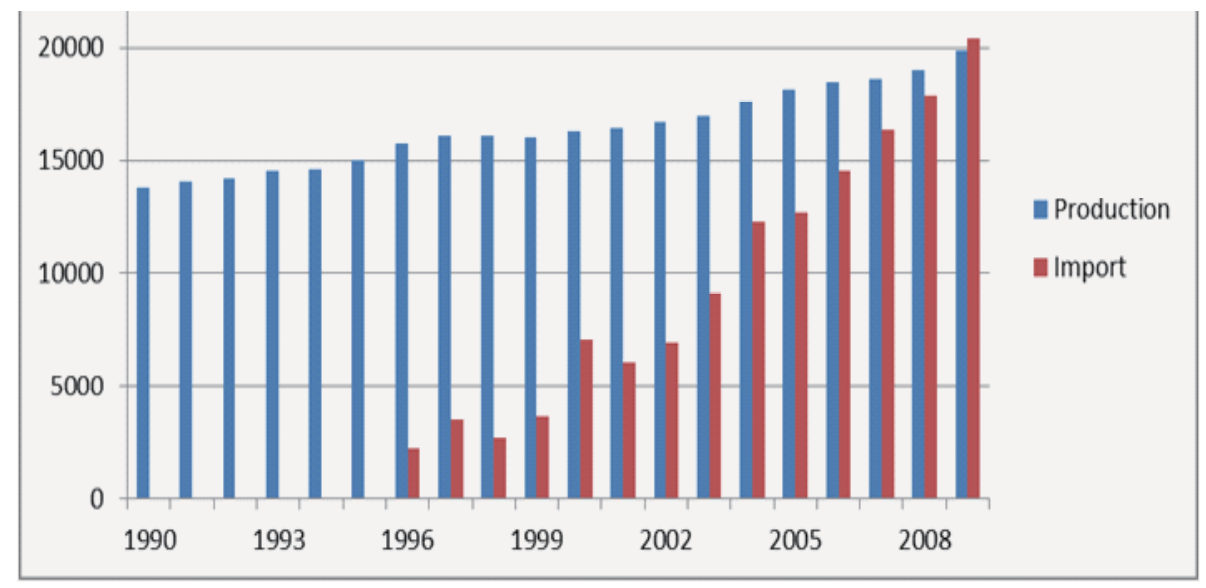

Figure 2: China's Crude Oil Production and Import (10,000 ton)

Note: Import through custom only, excluding ships and airplanes filling out of border.

Source: The author calculates figures from China Industry Economy Statistical Yearbook 2007, and China Statistical Yearbook several years.

Meanwhile, the rise of China is also posing new issues not observed before in steel manufacturing and its raw material, iron ore. China is the world's biggest crude steel producer. Its crude steel production was 568 million metric tons in 2009, accounting for $46.6 \%$ of the global total. It is also one of the biggest iron ore producers in the world with an output of 700 million metric tons (however, the figure adjusted to correspond to the world average is 332 million metric tons due to the steel being of low quality, 2007 figures). China ranks first in the import of iron ore because of booming domestic demand. In terms of import volume in 2007, China was ranked first at 383 million metric tons and Japan was ranked second at 139 million metric tons. The sum of the two countries accounted for $61 \%$ of the global total.

An interesting point is that China broke the traditional convention for determining the international price of iron ore. ${ }^{6}$ For over 20 years, the international price of iron ore had been decided after Vale, the world biggest miner, and Nippon Steel, the biggest customer had had thorough discussions over the price for around three months

\footnotetext{
5 People's Daily (29 July 2009).

6 The Nihon Keizai Shimbun (21 July 2010).
} 
while taking into account each other's business environment. The negotiation between these two companies is called a "benchmark negotiation", in which the benchmark price is decided through negotiations between the leading buyer and seller in the market. Other leading miners and resource companies then followed the price agreed to in the above negotiations. However, Vale unilaterally declared that it would discontinue such business practices and shift to a quarterly pricing system based on spot prices from 2010. In the new method, its quarterly iron ore price is matched with the market price of the latest three months. The market price, which replaced the benchmark negotiation price, is the spot price of iron ore produced in India for export to China.

Thus, the rise of China brought a substantial change to the pricing system of iron ore. Securing a stable source of resources became a new policy challenge for China, especially because it needs to hedge price volatility. State-run companies are requested by the government to boost the acquisition of mines and resource development companies but such moves are creating a backlash from developed countries. ${ }^{7}$

\section{Clashes in Developing Markets}

Chinese firms' expansion to foreign markets is prominent in the resource and energy fields, and their rapidly increasing presence in developing markets is causing frictions with developed countries. This is typically observed in the African market.

China began to strengthen its relationship with African countries in earnest when it hosted the Forum on China-Africa Cooperation in October, 2000 which led to regular meetings between those parties. ${ }^{8}$ China's motives for strengthening relations with African countries include the political tug-of-war with Taiwan, but its main motive is to secure natural resources and markets for products made in China. In 2008, crude oil comprised $69 \%$ of all items imported from Africa, and ore including iron, manganese, chrome, copper and diamond comprised 12\%. In bilateral trade, $70 \%$ of imports from South Africa were mineral resources including iron ore and precious stones such as platinum and diamond, $90 \%$ of imports from Congo was crude oil, and more than $80 \%$ of imports from Zambia were refined copper (the figures in 2009).

\footnotetext{
7 In 2005, China National Offshore Oil Corporation (CNOOC) proposed an acquisition of Unocal Corporation, an American oil and gas company, at 18.5 billion dollars, but the American government rejected the acquisition insisting that the Chinese government tried to obtain assets across the world with an iron fist. In 2009, Chinalco, a Chinese aluminum group firm, tried to invest 19.5 billion dollars in Rio Tinto, a leading Australian resource company, but the plan collapsed as a result of political opposition from Australian side: The Nihon Keizai Shimbun (6 August 2010).

8 Imamura, Hiroko, "Saidai No Hatten Tojokoku No Keizai Gaiko" [Economic Diplomacy of the Biggest Developing Country], in Kato, Hiroyuki and Uehara, Kazuyoshi, Gendai Chugoku Keizai Ron [Modern Chinese Economy] (Kyoto: Minerva Shobo, 2011), pp.279-296.
} 
Meanwhile, the main items exported to Africa are miscellaneous products for dayto-day use and household appliances such as clothing, shoes, toys, motorcycles, telephones and watches. Contract work for infrastructure construction such as roads and bridges is also rapidly increasing.

Friction with developed countries is not noticeable as of now, but China's sharply increasing presence in the African market will inevitably affect developed countries' firms entering into the market and the way their governments provide economic aid. According to a survey of Japanese firms that entered the African market conducted by JETRO (from July to September, 2007), 45.9\% of them answered that they were affected by the intensifying competition with Chinese firms and products, which implies that China's presence is becoming a threat. China's influence in the African economy can also be seen as a blistering criticism on developed countries, especially former colonial powers, which have extended economic aid to Africa for many years. Moyo, who is critical of developed countries' aid to Africa, argues as follows: "Western countries provided aid to Africa and did not care about the results. This created vested interest groups and excluded a vast number of people from wealth, which led to political instability. ${ }^{9}$ On the other hand, China sent cash to Africa and demanded returns. The returns improved the lives of the African people by providing jobs, roads and food."

\section{Fragile Economic Recovery Dependent on China}

The Chinese government announced a public investment of 4 trillion Yuan $(\$ 585.5$ billion) in immediate response to the bankruptcy of the Lehman Brothers, and was quick to achieve a V-shaped recovery in the first half of 2009. There is no doubt that China's V-shaped recovery contributed to putting the global economy back on the track of recovery while Japan and other countries were suffering from the global recession. This marked an emergence of an image of "China saving the world", but is China's economic growth sustainable?

First, from a short term perspective, economic management that is overly dependent on public investments will reach a limit, and accumulating non-performing loans could cause the burst of an economic bubble. China itself is well aware of the need to lessen its dependence on foreign demand and investment, and increase dependence on domestic demand from private sectors, but it has not created a new model that would replace the preceding successful model. Also, it was reported by a newspaper that about one fifth of the 7.7 trillion yuan in loans from commercial banks to local government banks had problems, and that non-performing loans with problems in the

\footnotetext{
${ }^{9}$ Dambisa Moyo, Dead Aid: Why Aid is not Working and How There is a Better Way for Africa (New York: Farrar, Straus and Giroux 2009), p.159.
} 
borrower's paying ability or collateral amounted to about 1.54 trillion Yuan (\$ about $225.4){ }^{10}$

Second, the sustainability of growth should be discussed from a mid-to-long term perspective. The rise of China and other newly industrialized economies is generating huge demand for resources and energy, and it is posing a threat to the environment worldwide. Global carbon dioxide emissions in 2008 were 29.5 metric tons and the total of the US, Russia, India and China exceeded half of the global total at $51.7 \%$. China, whose per capita income was only 3400 dollars, already had the largest carbon emissions at $22.1 \%$ of the world total, far ahead of the US, which was in second place at $19.2 \%$.

Concern toward the global environment has been rising in recent years, and the burden on the global environment is already beyond an acceptable level. According to the calculations of the "ecological footprint" 11 in 2002, the US had the highest value at 5.5 (meaning it would take 5.5 planet earths to support the world population if everybody had the same lifestyle as American people), Japan was at 2.4, and even the global average was at 1.3 indicating that more than one planet earth is required. It is obvious that our planet will not be able to bear the burden of China and other newly industrialized economies if they were to follow the production and consumption patterns adopted by developed countries.

\section{Vulnerability of the Global Financial System Underscored by China}

As Iwai pointed out correctly, the instability of global capitalism is rooted in "the crisis of the US dollar" as a key currency. ${ }^{12}$ The value of the dollar is maintained as almost all market participants trust and accept the dollar as a key currency. China, a country that has not liberalized exchange rates, supports the dollar by spending massive foreign reserves to purchase it. This structure is not desirable for China and definitely not healthy in terms of the stability of the global financial system.

China's foreign reserves started to increase not so long ago. They totaled \$105 billion in 1996, but started to rapidly swell around 2000, and grew to $\$ 3.2$ trillion as of

\footnotetext{
${ }^{10}$ The Nihon Keizai Shimbun (8 August 2010).

11 The ecological footprint is defined as the total 1) forest area needed to absorb carbon dioxide emissions from fossil fuel consumption 2) land used for roads and buildings 3) land required for food, and 4) land needed to produce paper and wood, under the assumption that everyone on the planet enjoys the same living standards of each country: Ryutaro Otsuka, "Hyakuoku Nin Jidai Wo Do Mukaeruka" [How We Face the Age of Ten Billion Population], in Norihiko Fukai, ed., Kobo No Sekaishi 20 [Rise and Fall of the World History 20], (Tokyo: Kodansha, 2009), pp. 71-120.

12 Katsuhito Iwai, Nijiuisseiki No Shihonsyugi [Capitalism in the 21st Century] (Tokyo: Chikuma Shobo, 2000).
} 
the end of August, 2011. ${ }^{13}$ Obviously, this means that China is bearing a huge risk of dollar depreciation with its immense foreign reserves. In early 2011, Chinese President $\mathrm{Hu}$ Jintao criticized the current US dollar based financial system saying, "the current international currency system is a relic of the past", and expressed strong dissatisfaction with the current situation in which US monetary policies could have a substantial impact on the Chinese domestic economy. ${ }^{14}$ However, no matter how unhappy China is with the current financial system, it is not possible to replace the US dollar with the Chinese yuan.

In the past, Japan and Germany also had purchased large amounts of US treasuries over a long period of time and maintained the value of the dollar in the same way that China does now. In that sense, today's China partly resembles the Japan and Germany of the past, but it should be noted that China's foreign reserves in recent years far exceed those of Japan and Germany in the past. The ratio of US dollar reserves to GDP of Japan and Germany from 1955 to 1975 did not exceed 2\%, but that of China today is over $12 \%$. Also, the ratio of foreign currency reserves to GDP of Japan and Germany then was a little over $5 \%$, while that of China today exceeds 50\%. ${ }^{15}$ Furthermore, Japan started to see an increase in net external assets after the end of the high economic growth period in the 1980 s, while China is already experiencing it in the midst of high economic growth unlike Japan.

Securing the stability of the current global financial system holds significance for both China and the global economy. Does China have enough economic power to bear the responsibility it carries? If it does, can we expect China to behave the same way as Japan and Germany? The answers for these questions are not clear yet.

\section{Significance of China's" Resurgence" from a Historical Point of View}

The analysis of the preceding sections has made clear the fact that China has steadily globalized since the reform and opening-up policy, and the consequent rapid increase of its presence brought certain types of uncertainties to the global economy. This

\footnotetext{
13 The traditional rule of thumb for foreign currency reserve adequacy is one year short-term debt and three month's exports on a practical level. According to this, China only needs 350 billion to 370 billion dollars based on its performance in 2010 .

${ }^{14}$ The Nihon Keizai Shimbun (17 January 2011).

15 Weiying Zhang, "Jingti Xiayici Weiji" [Watch out for the Next Crisis] in Weiying Zhang, ed., Jinrong Weiji Hou De Zhongguo Jingi [The Chinese Economy after the Financial Crisis] (Shanghai: Shanghai People's Publishing House, 2010) pp.80-85.
} 
section takes a slightly different angle and discusses the world historical significance of China's globalization by reframing the current prosperity of China from a historical point of view.

\section{Three Phases of Long-term Economic Development}

Table 2 shows the longitudinal shift of GDP distribution of the world's major regions. ${ }^{16}$ The transitions that the world's economic core regions went through in the recent 300 years can be seen from this chart. From 1700 to 1820, China's GDP ratio to the global total grew by more than $10 \%$ up to $32.9 \%$. However, Europe also showed a slight increase in its ratio, so it is not correct to say Europe had been stagnant. Meanwhile, India's ratio fell by a large margin.

\begin{tabular}{c|r|r|r|r|c}
\hline Year & 1700 & 1820 & 1952 & 1978 & 2003 \\
\hline China & 22.3 & 32.9 & 5.2 & 4.9 & 15.1 \\
\hline India & 24.3 & 16.0 & 4.0 & 3.3 & 5.5 \\
\hline Japan & 4.1 & 3.0 & 3.4 & 7.6 & 6.6 \\
\hline Western Europe & 21.9 & 23.0 & 25.9 & 24.2 & 19.2 \\
\hline U.S.A. & 0.1 & 1.8 & 27.5 & 21.6 & $20.6(\%)$ \\
\hline
\end{tabular}

Table 2: Shares of World GDP, 1700-2003

Source: Maddison, Angus, Chinese Economic Performance in the Long Run (OECD: 2007), p.103.

According to Sugihara, the first phase of development was from 1500 to 1820 , and Europe and Asia took different paths to development. ${ }^{17}$ Although interdependent relations existed as silver, which was found in the New World, flowed into China and affected price levels, the two paths did not converge. However, East Asia, especially Japan and coastal areas of China, developed as much as Europe and maintained a per capita GDP that stacked up against that of Europe. ${ }^{18}$

The second phase of development is from the early 19th century, when the Industrial Revolution caused a great upheaval, to the first half of the $20^{\text {th }}$ century. Industry spread throughout Europe and a European settlement (The United States) to form the

\footnotetext{
${ }^{16}$ Angus Maddison, Chinese Economic Performance in the Long Run: 960-2030, $2^{\text {nd }}$ Edition (Paris: OECD, 2007).

${ }^{17}$ Kaoru Sugihara, "The East Asian Path of Economic Development," in Giovanni Arrighi, Takeshi Hamashita and Mark Selden, eds., The Resurgence of East Asia (New York: Routledge, 2003), pp.78-123.

18 Saito argues: "if a paid worker from a typical household in a rual part of England in the latter half of the $18^{\text {th }}$ century is compared with a farmer from a typical household in an agricultural village of East Asia, then the farmer's disposable income, and not his real wage, would be about $10 \%$ higher than the latter in the case the latter was a tenant farmer, and it would be about the same as that of the latter in the case that the latter was a land-owning farmer: Osamu Saito, Hikaku Keizai Hatten Ron [Comparative Economic Development Theory] (Tokyo: Iwanami Shoten, 2008), p.186.
} 
transatlantic economic region. Table 2 shows a significant decline in the ratio of China and India's GDP to the global total while Europe and the US came to the forefront. The ratio of Europe and the US's GDP to the global total in 1952 was an overwhelming $56.8 \%$. As indicated by K. Pomeranz, "the Great Divergence" emerged between Europe (the United Kingdom) and China (Yangtze river delta), both of which had been following the path of development. ${ }^{19}$

Even today, there is much controversy over why the Industrial Revolution occurred in Europe but not in Asia. Several factors including the following have been discussed: only Europe had exclusive access to the resources in the New World; cheap fuel (coal) was available in the UK; the wage level was high and capital was relatively plentiful in Europe before "the Great Divergence", which promoted the development of laborsaving and capital-intensive industries; and the difference in natural geographical conditions created the difference between the decentralized governance of Europe and centralized governance of China. ${ }^{20}$

While Europe and China showed "the Great Divergence", Japan developed in a way unique among Asian countries. Sugihara sees Japan's experience of the pre-war period as a successful example of labor-intensive industrialization. In other words, Japan underwent a process to catch up to Europe independently by successfully developing industrial products suitable for Asia where labor force is relatively abundant, such as cotton textiles and noodle-making machines. However, Sugihara argues that the growth of Japan's GDP share in the global economy was limited because its labor-intensive industrialization was behind that of Europe in terms of labor productivity.

The third phase of development refers to the period from the second half of the $20^{\text {th }}$ century to today. Japan succeeded in heavy industrialization in the unique international environment of East Asia and became one of the global production sites for the manufacturing industry. ${ }^{21}$ Then, production sites gradually spread from Japan to Asian newly industrialized economies (Hong Kong, Taiwan, Korea, Singapore) and eventually to ASEAN countries as well as coastal regions of China in line with the flying geese pattern of development. China joined the trend from 1978 when the reform and opening-up policy was introduced, and rapidly pushed up its GDP share in the global economy.

Would the rapid growth of East Asian that started in the latter half of the 20th

\footnotetext{
${ }^{19}$ Kenneth Pomeranz, The Great Divergence (Princeton: Princeton University Press, 2000).

20 Giovanni Arrighi, Adam Smith in Beijing (London: Verso, 2007); Jared Diamond, Guns, Germsnd Steel: the Fates of Human Societies (New York: W.W. Norton, 1997).

${ }^{21}$ Sugihara indicated that the structure of the Cold War between West and East created an external environment for industrialization in East Asia, saying that "Asia-Pacific zone dynamics and the Cold War regime complemented one another in a mutually defining way as the Cold War regime ensured a trade order whereas the growth in East Asia symbolized the superiority of the West and encouraged the US to specialize in the military industry," Sugihara op. cit., p.28.
} 
century and accelerated by the rise of China create "the Great Convergence" of the disparity between Europe and Asia originally caused by "the Great Divergence"? Theories and experimental studies of economic growth theory support this conclusion. Based on the neo-classical growth model formulated by R. Solow and developed by P.Romer, under the assumption that "technology is a public good," 22 a country with a lower per-capita income at the beginning grows faster and all economies will "converge" to a steady state $^{23}$ Some experimental results show that the "convergence" would not happen among all countries but only among a group of countries that share the same conditions considering that each country has different personnel and material resource stocks. Either way, there is no doubt that the process of former developing countries catching up with developed countries took place in East Asia.

\section{How Should the "Resurgence" of China be Interpreted?}

If what Sugihara calls the third phase of development continues to keep the current momentum, the economic map of the world will be significantly redrawn. According to a long term forecast by Goldman Sachs, China's GDP will exceed that of the US in 2041 and exceed the US GDP by $26 \%$ by 2050 . By then, the economic scale of BRICs countries (Brazil, Russia, India and China) will be 55\% larger than that of the G6 (the US, the UK, Japan, Italy, Germany and France). ${ }^{24}$

The advance of China is especially remarkable among rising emerging economies. A.G. Frank interprets the rise of China as its "resurgence", saying that "the world is about to reorient (from West to East) as China begins to prepare for taking the dominant position in the global economy which it had lost for a while since 1800." 25

Apart from whether or not the long-term forecast by Goldman Sachs is accurate, many agree that China's economy will catch up to that of the US in size in the not too distant future. The question is the significance of this. As Frank himself admits, the "resurgence" of China is not simply the theory of "Sino-centrism" replacing the theory of "western-eurocentrism". Even if the world reverts to what it was in 1820,

\footnotetext{
22 Refers to the assumption that technology level is approximately same in all countries throughout the world and the same products can be made anywhere if the same amount of real capital and labor are invested.

23 This model assumes a linear economic growth, but economic structural changes could lead to a non-linear path. In that case, verification to test the hypothesis of "convergence" would not make sense: Tokuo Iwaisako, "Keizai Seicho No Jissho Kenkyu" [Experimental Study of Economic Growth], in Takatoshi Ito and Tetsushi Sonobe, Kozo Henka Wo Tomonau Higashi Ajia No Seicho [Growth of East Asia with Structural Change], Keizai Bunseki [The Economic Analysis] (No. 160, January 2000), pp.59-92.

${ }^{24}$ Dominic Wilson, Roopa Purushothaman, "Dreaming With BRICs: The Path to 2050", Goldman Sachs Global Economics Paper No. 99 (October 2003) at <http://www.goldmansachs.com/ ceoconfidential/CEO-2003-12.pdf $>$ (searched date: 18 April 2012).

${ }^{25}$ Andre Gunder Frank, ReOrient: Global Economy in the Asian Age (Berkeley: University of California Press, 1998), trans. Beicheng Liu, Ziben Baiyin, Zhongshi Jingji Quanqiuhuazhong De Dongfang (Beijing: Central Compilation and Translation Press, 2008), p. 3.
} 
China would not be the only center of the world but merely one of several core regions. However, it is too optimistic to believe that China's advance will not shake the existing world order as J.Anderson argues, because increasing uncertainties caused by the rise of China can be seen as signs that the world order of "western-eurocentrism" centered around the US has begun to change, as discussed in the previous section. ${ }^{26}$

The advance of globalization enhances the interdependence of the world more than ever. Given this situation, what would the reemerging multipolarized world look like and what kind of role would a "resurging" China play in such a world?

Sugihara pointed out the following two implications of the third phase of development in the context of global history. First, resurgence and expansion of the East Asian development model would be able to terminate global income expansion. Second, it could contribute to retaining and promoting resource saving technologies. ${ }^{27}$ Sugihara focuses on the fact that the spread of industrial development from Western Europe to East Asia alleviated the widening income disparity between Western countries and non-western countries, and that the East Asian development model is superior in terms of resource efficiency with its use of labor-intensive technology.

China should be included in the third phase of development. However, does China's development pattern represent what Sugihara calls the East Asian development model? G. Arrighi, based on Sugihara's study, lauds China's development pattern saying that it is not a mere replication of the Western development model but "is mainly dependent on internal accumulation of wealth and focuses on mobilization of personnel resources [...] a development model based on the domestic market." 28

Indeed, China's development centered around the manufacture of labor-intensive products dependent on low cost labor. Its dependence on labor intensive technology can be regarded as a characteristic of the East Asia development model which is different from the Western development pattern. However, China's development pattern can hardly be seen as resource-saving, the second condition by Sugihara. Rather, it is generally assessed as an extensive resource consuming way of development. ${ }^{29}$ Also, although the internal accumulation of wealth and the domestic market surely played roles in the process of development, foreign capital brought in by opening-up and the international market (especially the US market) played even more important roles. In

\footnotetext{
26 Jonathan Anderson, Shenhua Zouchu, Zhongguo Bu Hui Gaibian Shijie de Qige Liyou [Escaping from Myth: Seven Reasons that China would not Change the World] (Beijing: China Citic Press, 2006).

${ }^{27}$ Kaoru Sugihara, Ajia Taiheiyo Keizaiken No Koryu [The Rise of the Asia Pacific Economy] (Osaka: Osaka University Press, 2003).

${ }^{28}$ Giovanni Arrighi, Adam Smith in Beijing (London: Verso, 2007), p. 389.

${ }^{29}$ According to the international comparison of the amount of primary energy supply per GDP in 2007, when Japan is normalized to 1, the US is at 2.1 and China is at 8.3: Ministry of Economy, Trade and Industry, Agency for Natural Resources and Energy, Energy White Paper 2010, at <http:// www.meti.go.jp/english/press/data/pdf/20100615_04a.pdf $>$ (searched date: 18 April 2012).
} 
this respect, Arrighi's assessment seems to reflect only one side of the reality of China.

These discussions illuminate the problem. That is, China's development pattern so far represents a mixture between what Sugihara argues as the characteristics of the third phase of development and what he argues is not. China's further development according to the current model will not fit the East Asian development pattern which is different from that of Western Europe. Neither does it seem to be sustainable. Jinglian $\mathrm{Wu}$, one of representative Chinese economists, has been insisting from an early stage that a shift in development model is necessary. ${ }^{30} \mathrm{He}$ also mentioned that the shift in development model would pose considerable difficulties, but this article will not touch upon this. ${ }^{31}$ What should be emphasized is that China's growth will be sustainable and its "resurgence" will become a reality only when China succeeds in the shift to a laborintensive, resource and energy saving, domestic market-based development model, which is what Sugihara calls the East Asian development pattern.

\section{The Near Future - Two Scenarios}

In the mid-to-long term, it is highly probable that a Western Europe centered global economy will be replaced by a new world order in which several core regions coexist. The US dollar based financial system will remain for a while, but the current global financial system will be forced to go through a significant change in the mid-to-long term. Also, an energy consumption pattern will shift from one in which consumption is dominated by one billion people in developed countries to one in which consumption is shared by four billion people including those from China, India and other emerging economies. The current industrial and consumption structure will be forced to change fundamentally during this process.

The question is what scenario prevails in the near future in the process of forming such a new world order. In a desirable scenario, the transition to create a new world order having China as one of several core countries will happen smoothly. In a less desirable scenario, emerging economies will continue to employ the resource and energy intensive development pattern. Consequently, there would be increasing conflicts and friction over resources and markets, and uncertainty in the global economy would grow to the point that the economic order is destroyed.

\footnotetext{
${ }^{30}$ Jinglian Wu, "Zhongguo Jingji Zhuanxing De Kunnan Yu Chulu” [Shift of the Chinese Economy's Difficulties and Solution], Zhongguogaige [Chinese Reform], No. 2 (February, 2008), pp. 69-71.

${ }^{31}$ The need for such shift was already discussed in 1995, but it did not happen. Jinglian Wu mentions three reasons for that. First, each level of government has authority to allocate important resources. Therefore, a large portion of land and other production factors is allocated not through the market. Second, GDP growth is used as a major index of policy evaluation by each level of government. Third, financial income of each level of government is largely dependent on value added tax. Thus, the government has to focus on the development of the manufacturing industries whose performance directly affect the amount of value added tax.
} 
Which scenario takes place depends upon the future direction of China's globalization. Our world cannot simply exclude China for being a cause for uncertainty. The world has already reached a phase in which there is no choice but to integrate China into its system. China is indispensable as it provides a huge market for developed countries and serves as a supplier of inexpensive consumer goods and an intrepid investor for developing countries. However, the more important China's sustainable growth is for the global economy, the longer it might take for China to shift from the current development model, because an extensive development model is more likely to generate extensive growth. The world will not change unless China changes. A paradigm shift will be inevitable in the mid-to-long term, but the path for it is still unclear at the moment.

\section{References}

Anderson, Jonathan, Zouchu Shenhua, Zhongguo Bu Hui Gaibian Shijie de Qige Liyou [Escaping from Myth: Seven Reasons that China would not Change the World] (Beijing: China Citic Press, 2006).

Arrighi, Giovanni, Adam Smith in Beijing (London: Verso, 2007).

Diamond, Jared, Gun, Germs and Steel: The Fates of Human Societies (New York: W. W. Norton, 1997).

Frank, Andre Gunder, ReOrient: Global Economy in the Asian Age, (Berkeley: University of California Press,1998), trans. Liu, Beicheng, Baiyin Ziben, Zhongshi Jingji Quanqiuhuazhong De Dongfang (Beijing: Central Compilation and Translation Press, 2008).

Imamura, Hiroko, "Saidai No Hatten Tojokoku No Keizai Gaiko” (Economic Diplomacy of the Biggest Developing Country], in Kato, Hiroyuki and Uehara, Kazuyoshi, Gendai Chugoku Keizai Ron [Modern Chinese Economy] (Kyoto: Minerva Shobo, 2011), pp. 279-296.

Iwai, Katsuhito, Nijuisseiki No Shihonshugi Ron [Capitalism of the $21^{\text {st }}$ Century] (Tokyo: Chikuma Shobo, 2000).

Iwaisako, Tokuo, “Keizai Seicho No Jissho Kenkyu” [Experimental Study of Economic Growth], in Ito, Takatoshi and Sonobe, Tetsushi, eds., Kozo Henka Wo Tomonau Higashi Ajia No Seicho [Growth of East Asia with Structural Change], Keizai Bunseki [The Economic Analysis], No.160 (January 2000), pp. 59-92.

Kato, Hiroyuki and Kubo, Toru, Shinka Suru Chugoku No Shihonshugi [China's Evolving Capitalism] (Tokyo: Iwanami Shoten, 2009).

Maddison, Angus, Chinese Economic Performance in the Long Run: 960-2030, $2^{\text {nd }}$ Edition (OECD, 2007).

Moyo, Dambisa, Dead Aid: Why Aid Is Not Working and How There Is a Better Way 
for Africa (New York: Farrar, Straus and Giroux 2009).

Otsuka, Ryutaro, "Hyakuoku Nin Jidai Wo Do Mukaeruka" [How We Face the Age of Ten Billion Population], in Fukui, Norihiko, ed., Kobo No Sekaishi 20 [Rise and Fall of the World History 20] (Tokyo: Kodansha, 2009), pp. 71-120.

Pomeranz, Kenneth, The Great Divergence (Princeton: Princeton University Press, 2000).

Saito, Osamu, Hikaku Keizai Hatten Ron [Comparative Economic Development Theory] (Tokyo: Iwanami Shoten).

Sugihara, Kaoru, Ajia Taiheiyo Keizaiken No Koryu [The Rise of the Asia Pacific Economy] (Osaka: Osaka University Press, 2003).

Sugihara, Kaoru, "The East Asian Path of Economic Development," in Arrighi, Giovanni, Hamashita, Takeshi, Selden Mark, eds., The Resurgence of East Asia (New York: Routledge, 2003), pp. 78-123.

Wilson, Dominic and Purushothaman, Roopa, "Dreaming With BRICs: The Path to 2050," Goldman Sachs Global Economics Paper, No.99 (October 2003).

Wu, Jinglian, "Zhongguo Jingji Zhuanxing De Kunnan Yu Chulu” [Shift of the Chinese Economy's Difficulties and Solution], Zhongguogaige [Chinese Reform], No.2 (February 2008), pp. 69-71.

Zhang, Weiying, "Jingti Xiayici Weiji" [Watch out for the Next Crisis], in Zhang, Weiying, ed., Jinrong Weiji Hou De Zhongguo Jingji [The Chinese Economy after the Financial Crisis] (Shanghai: Shanghai People's Publishing House), pp.80-85.

\section{About the Author}

Hiroyuki KATO is Professor of Graduate School of Economics at Kobe University. He received his $\mathrm{MA}$ and $\mathrm{PhD}$ degree in economics from Kobe University. His research interests include Chinese economy, comparative economic systems and regional development policies. His recent publications include: Shinka Suru Chugoku No Shihonshugi [Evolving China's Capitalism], Tokyo, Iwanami Shoten, 2009, co-author Toru Kubo: Chengshihua yu Quyu Jingji Fazhan Yanjiu [A Study on Urbanization and Regional Economic Development], Shanghai, Huadongligong Daxue Chubanshe, 2011, co-editor Wu Baijun.

Address: 2-1 Rokkodai-cho Nada-ku, Kobe 657-8501, Graduate School of Economics, Kobe University, Japan.

Email: kato@econ.kobe-u.ac.jp 